\title{
Characterization of Anopheles gambiae s.l. and insecticide resistance profile relative to physicochemical properties of breeding habitats within Accra Metropolis, Ghana
}

\author{
BILALI I. KABULA ${ }^{1,2}$, PAUL K. ATTAH ${ }^{2,3}$, MICHAEL D. WILSON ${ }^{4}$ and DANIEL A. BOAKYE ${ }^{2,4}$ \\ ${ }^{1}$ National Institute for Medical Research, Tukuyu Research Centre, P.O. Box 538, Tukuyu, Tanzania \\ ${ }^{2}$ ARPPIS Sub-regional Centre for West Africa and Zoology Department, University of Ghana, Legon, Ghana \\ ${ }^{3}$ Zoology Department, University of Ghana, Legon, Ghana \\ ${ }^{4}$ Noguchi Memorial Institute for Medical Research, University of Ghana, Legon, Ghana
}

\begin{abstract}
Malaria is endemic in Ghana as in most countries of sub-Saharan Africa. This study was conducted to characterize Anopheles gambiae s.l. and determine pyrethroid resistance profiles relative to physicochemical properties of breeding habitats in Accra, Ghana. Eight aquatic habitats containing Anopheles larvae were identified and from each habitat, larvae and water were sampled. Adult An. gambiae reared from larvae were morphologically identified and tested for permethrin $(0.75 \%)$ and deltamethrin $(0.05 \%)$ resistance using WHO bioassay method. An. gambiae s.s. found were identified to their molecular levels and $k d r$ mutation detected using PCR-based methods. Twenty-nine physicochemical parameters of each water sample were measured and their levels connected with pyrethroid resistance and proportions of An. gambiae s.s. molecular forms in habitats. A total of 2,257 mosquitoes were morphologically identified as An. gambiae s.l. and all 224 processed for PCR were identified as An. gambiae s.s., of which $56.46 \%$ and $43.54 \%$ were $\mathrm{M}$ and S-forms, respectively. Both forms occurred in sympatry in all larval habitats and no S/M hybrids were detected. However, M-form larvae were in high proportion in polluted habitats than the S-form. An. gambiae s.s. was highly resistant to both deltamethrin and permethrin with mortality rates of $42.98-70.0 \%$ and $6.5-20.0 \%$ respectively. The frequency of $k d r$ mutation was $60.5 \%(\mathrm{n}=195)$. This mutation occurred in both $\mathrm{S}$ and $\mathrm{M}$-forms, but was mainly associated with the S-form $\left(X^{2}=10.92, \mathrm{df}=1, P=0.001\right)$. Carbonate and $\mathrm{pH}$ were both selected in discriminant function analysis as best predictors of high proportion of M-form in the habitats. The adaptation of An. gambiae s.s. in polluted aquatic habitats coupled with occurrence of insecticide resistance is quite alarming particularly for urban malaria control and needs further exploration in a wider context.
\end{abstract}

Key words: Anopheles gambiae, physicochemical properties, insecticide, resistance, malaria, Ghana

\section{Introduction}

The Anopheles gambiae complex is established to contain the main vectors that transmit malaria parasite, Plasmodium falciparum in sub-Saharan Africa (WHO 2000). Despite its importance as a vector, relatively little is known about the larval habitats' characteristics (Pfaehler et al., 2006). A number of environmental variables have been identified to have either direct or indirect effects on mosquito oviposition (Rejmànkovà et al., 2005), larval distribution, density and development (Gimnig et al., 2001; Oo et al., 2002; Mwangangi et al., 2007) as well as adult fitness (Briegel, 2003). These are important determinants of adult distribution and abundance, which subsequently determine the geographical pattern of malaria infection. Traditionally, malaria control has been directed to the adult stages and studies of larval ecology have been thought to be irrelevant by some workers (Gimnig et al. 2001). This has been the main reason for the dearth of information on factors affecting larval productivity and distribution. 
The importance of An. gambiae complex stems from the fact that it is highly anthropophilic and has the capacity to exploit different kinds of habitats that are created either directly or indirectly by humans; ranging from temporary sunlit pools, water collected in depressed soil by livestock and in ditches resulting from construction to permanent water bodies in rice fields and irrigation canals. This adaptive flexibility in exploiting different larval habitats is evidenced by its wide geographical distribution and its occurrence in a variety of micro and macro environmental conditions throughout tropical Africa (Lanzaro et al. 1998, Budiansky, 2002).

In urban environment, Anopheles mosquitoes adapt to new breeding sites created by urbanization (Afrane et al., 2004), and hence their ecology is likely to differ from the rural settings. The mosquito may breed in a variety of habitats in urban areas, including pools, borrow pits, trees holes, wells, puddles formed alongside lakes, footprints, vehicle ruts, gardens, water storage tanks, septic tanks, construction sites, drains and marshy areas (Afrane et al., 2004; Klinkenberg et al., 2005; Wang et al., 2005). Most studies of Anopheles larval ecology have been conducted in rural settings, where unpolluted breeding sites are found and described more often (Sattler et al., 2005), giving a biased impression. However studies conducted in Dares-Salaam, Tanzania revealed the presence of An. gambiae s.l. in sewage ponds and in swamps extremely polluted with organic matter (Sattler et al., 2005). Studies in Lahore, Pakistan and Accra, Ghana, also indicated the adaptation of the An. gambiae s.l. to breeding in organically polluted water habitats (Sibomana, 2002; Mukhtar et al., 2003).

The suitability of certain water bodies for An. gambiae s.l. breeding is a complex interplay of physical, chemical and biological parameters of water quality. In Benin, Akogbeto (1995) observed that population density and distribution of An. melas and An. gambiae s.s. were highly dependent on the level of urbanization and the salinity of a lagoon to the north of the capital city Cotonou. Elsewhere, physicochemical factors of the water, such as temperature, salinity, concentration of carbonates and nitrates have been shown to correlate with the presence or development quality of Anopheles larvae in pools (Robert et al., 1998; Gimnig et al., 2001; Oo et al,. 2002). Gimnig et al. (2001) reported the association of An. gambiae s.l. with water turbidity, algae, the absence of emergent vegetation, and small habitats. As the result of its ability to adapt to a wide variety of micro and macro-environmental conditions, it is clear that An. gambiae s.l. can breed in nearly every kind of water accumulation in the urban settings (Sibomana, 2002; Sattler et al., 2005) as evidenced by its wide geographical distribution.

The diverse mosquito breeding habitats expose the larvae to bacterial toxins, plant allelochemicals, toxic phenolic products of plant degradation and environmental pollutants such as pesticides (Strode et al., 2006). These have necessitated the development of extensive families of detoxification enzymes (cytochrome $\mathrm{P}_{450}$, carboxylesterases and glutathione Stransfereases) as an adaptive response (Strode et al., 2006). The extensive development of these enzymes may have an influence on emergence of insecticides resistance in Anopheles mosquitoes. Thus improving our knowledge of the bioecology of mosquito aquatic stages, with detailed analysis of factors that are essential to the maintenance of mosquitoes is critical for malaria control.

Though several studies on resistance of An. gambiae s.l. to insecticides have been conducted in Ghana (Adasi, et al., 2000; Adeniran, 2002; Otieno, 2004; Yawson et al., 2004; Achonduh, 2005; Kahindi, 2005), it is still important to continue monitoring changing trends of 
resistance. The information provides a basis for ascertaining continued susceptibility to and efficacy of pyrethroids, and for vector insecticide resistance management. In an earlier study, Sibomana (2002) identified physico-chemical parameters of water that determine the distribution of An. gambiae s.s. larvae in Accra. However he did not attempt to differentiate the aquatic habitat usage of An. gambiae s.s. $\mathrm{M}$ and $\mathrm{S}$ molecular forms, neither did he look on the relationship between physico-chemical parameters of breeding water and distribution of insecticide resistance in An. gambiae s.s. Therefore this study was carried to characterize $A n$. gambiae s.l. and determine their pyrethroid resistance profiles relative to physicochemical properties of their breeding habitats in the urban Accra in Ghana. Knowledge of the differences in aquatic habitat usage between the members of $A n$. gambiae complex, molecular forms of $A n$. gambiae s.s., and their insecticide resistance profile are important in understanding their adaptation to breed in polluted water and to effective malaria control strategies in the urban settings.

\section{Materials and Methods}

\section{Study sites}

Mosquito larvae and pupae and water from their habitats were collected from Metropolitan Accra, in the Greater Accra Region of southern Ghana. The Accra Metropolitan area is the country's biggest, most diverse and most cosmopolitan city with estimated population of 1.9 million people. Accra is located in the coastal savanna ecological zone, which is characterized by dry climatic conditions. It has two rainfall peaks, the first occurring April to June and the second from September to October. The region receives rainfall between 740 and 890mm per year. The lowest mean monthly temperature (about $26^{\circ} \mathrm{C}$ ) is recorded during August and the highest (about $30^{\circ} \mathrm{C}$ ) between March and April. The relative humidity throughout the year ranges between $65 \%$ and $75 \%$. There are few streams and ponds which usually dry out during the dry season.

The study area was surveyed on foot to locate breeding sites. Samples were obtained from a variety of breeding sites, including gutters, ponds, and small pools of stagnant water, muddy water, and runoff from houses and irrigated vegetable farms at Korle-bu, Madina and Legon. The collections were conducted from September to December 2006. Sampling covered a period of the final part of a short rainy period and continued towards the dry period. Most of the breeding sites were shallow and exposed directly to sunshine with different qualities of water. Most water contained organic debris with filamentous green algae floating on the surface.

\section{Field sample collections}

Anopheles larvae identified from their horizontal position on the surface of water and other species identified by their angular position were carefully collected with a $350 \mathrm{ml}$ dipper and transferred into $5000 \mathrm{ml}$ plastic containers which were then loosely capped to allow aeration. Water samples were collected immediately thereafter into a 1.51 plastic bottles for physicochemical analyses. For the estimation of dissolved oxygen (DO), a 300-ml brown glass bottle (covered with aluminium foil to shield its content from light), was filled almost to the brim and $2 \mathrm{ml}$ of manganese sulphate solution, and $2 \mathrm{ml}$ of alkali-iodide-azide solution added to fix the 
oxygen. The temperature of each habitat was also recorded as well as its geo-location using a global positioning system (GPS). To control for variability of water parameters, the sampling for each breeding site was done only once between 11.00 and $13.00 \mathrm{hrs}$. The samples were then transported to the laboratory under cool conditions.

\section{Laboratory rearing of mosquitoes}

Once in the insectary of Noguchi Memorial Institute for Medical Research (NMIMR), the water with pre-adult mosquitoes was poured into plastic trays $(5 \mathrm{~cm} \times 27 \mathrm{~cm} \times 36 \mathrm{~cm})$ to a depth of approximately $2 \mathrm{~cm}$ and each tray labelled to reflect the site and date of collection. The trays containing mosquito larvae were kept at $27-30^{\circ} \mathrm{C}$ and $76 \pm 5 \%$ relative humidity with a $12 \mathrm{~h}: 12 \mathrm{~h}$ light and dark cycle. Every two days, about 200mg of ground Nutrafin goldfish food (Rolf Hagen, USA) was used to feed the larvae. The development of the larvae were monitored regularly and all those that pupated collected into shallow plastic cups /small beakers using Pasteur pipettes, and then placed in appropriately labelled cages for adult emergence. All emerged mosquitoes were fed on $10 \%$ sugar solution imbibed in cotton wool. Only 2-5 days old female adult mosquitoes were picked from the cages and used for bioassays. Where the number of adults emerged were not enough to run the insecticide susceptibility test, they were made to feed blood from guinea pig to lay eggs. In such cases $F_{1}$ were used for the bioassays test.

\section{Identification of Anopheles mosquitoes}

All the adult mosquitoes were separated from other species by morphological means (Gillies \& de Meillon 1968; Gillies \& Coetzee 1987) to the genus and in the case of anophelines to the species level. An. gambiae s.l. genomic DNA was extracted using the method of Collins et al. (1987) and Polymerase Chain Reaction (PCR)-based methods were used for the identification of the member species of An. gambiae complex (Scott et al. 1993). Identification of An. gambiae s.s. molecular forms was based on PCR-restriction fragment length polymorphism method of Fanello et al. (2002). Amplified fragments were analysed by electrophoresis on a $2 \%$ ethidium bromide agarose gel and were visualised under ultraviolet light.

\section{Insecticide susceptibility/resistance bioassay tests}

Insecticide susceptibility/resistance bioassay tests were carried out using susceptibility test-kits (WHO, 1975) and standard procedures (WHO, 1998) with 5 replicates of 20-25 non-blood-fed adult female mosquitoes of 2-5 day-old per test tube. Mosquitoes were exposed to papers impregnated with the WHO recommended discriminating concentration $(\mathrm{v} / \mathrm{w})$ of $0.05 \%$ deltamethrin and $0.75 \%$ permethrin prepared at University Saint Malasyia (WHO, 1998). These two insecticides were chosen because they are recommended by WHO and used in Ghana for the treatment of mosquito nets and also used to control agricultural pests. The controls were exposed to non-impregnated papers. During the exposure period, the number of mosquitoes knocked down (KD) was recorded after 5, 10, 15, 20, 30, 40, 50 and 60 minutes. Mosquitoes were then transferred into the holding tube and fed on glucose solution. Where the number knocked down after 60 minutes is less than $80 \%$, number knocked down were recorded for further $20 \mathrm{~min}$ (i.e. after $80 \mathrm{~min}$ ) in the holding tube. Mortality was recorded $24 \mathrm{hr}$ post-exposure. Times for $50 \%$ and $90 \%$ knockdown $\left(\mathrm{KDT}_{50}\right.$ and $\mathrm{KDT}_{95}$ ) were assessed using log-probit analysis. 


\section{Detection of knock down resistance ( $k d r)$ alleles in Anopheles gambaie s.s.}

PCR genotyping to detect the standard Leu-Phe ' $k d r$ ' allele (conferring knockdown resistance to pyrethroids) was performed on An. gambiae s.s. using Martinez-Torres et al. (1998) technique. The amplified fragments were analysed by electrophoresis on a $2 \%$ ethidium bromide agarose gel and were visualised under ultraviolet light.

\section{Physico-chemical parameters of water samples}

A total of 29 parameters were measured from the total of eight water samples collected from eight An. gambiae breeding sites using standard methods described by American Public Health Association et al. (1998). These were turbidity, temperature, $\mathrm{pH}$, electrical conductivity, suspended solids (SS), total dissolved solids (TDS), total hardness, total alkalinity, calcium hardness, magnesium hardness, biological oxygen demand (BOD), chemical oxygen demand (COD), dissolved oxygen (DO), sodium, potassium, calcium, magnesium, total iron, ammonium, chloride, sulphate, silica, nitrite, nitrate, phosphate, fluoride, bicarbonate and carbonate.

\section{Data Analysis}

Percent mortality was corrected by Abbott's formula when mortality in control replicates was $>5 \%$ (Abbott, 1925). Tests where control mortality exceeded 20\% were excluded from analysis. The $\mathrm{KDT}_{50}$ and $\mathrm{KDT}_{95}$ values were estimated from the time-mortality regression using Probit analysis (Finney, 1971). A one-way analysis of variance (ANOVA) was used to compare insecticide resistance profiles in different breeding sites. Chi-square test $\left(\mathrm{X}^{2}\right)$ was used to test for relationships between molecular forms and $k d r$ allele. The principal component analysis (PCA) was used to examine the relationships (interaction effects) among all 29 physicochemical parameters of water measured. The relationship between physiochemical properties of water, distribution of An. gambiae s.s. molecular forms and $k d r$ allele, and insecticide resistance profiles was determined using correlation coefficient and multiple regressions. To select water parameters, which were most useful in distinguishing the habitats of An. gambiae s.s. M-form and S-form, discriminant function analysis (DFA) was used. All levels of statistical significance were determined at $P<0.05$. Statistical analyses were carried out using SPSS version 11.5 for Windows (SPSS Inc, USA).

\section{Results}

\section{Identification of An. gambiae species complex}

A total of 2,257 mosquitoes selected from eight breeding sites were morphologically identified as An. gambiae s.l. Of these, 224 An. gambiae s.l. were processed for molecular identification and all identified as An. gambiae s.s. This was indicated by the diagnostic size of amplified DNA fragment which is $390 \mathrm{bp}$. Of the 224 An. gambiae s.s., 209 were further identified to their molecular forms. Out which, 118 (56.46\%) were M-form while 91 (43.54\%) were S-form. The M and $\mathrm{S}$ forms were sympatric in all eight breeding sites (Table 1). 
Table 1: Distribution of An. gambiae s.s. M and S forms at different breeding sites

\begin{tabular}{llll}
\hline & & \multicolumn{2}{c}{ Distribution of molecular forms (\%) } \\
Site & $\mathbf{n}$ & $\mathbf{M}$ & $\mathbf{S}$ \\
\hline Korle-bu I & 27 & 77.8 & 22.2 \\
Korle-bu II & 22 & 86.4 & 13.6 \\
Korle-bu III & 25 & 84 & 16 \\
Korle-bu IV & 25 & 68 & 32 \\
Madina I & 30 & 53.3 & 46.7 \\
Madina II & 20 & 35 & 65 \\
Madina III & 29 & 24.1 & 75.9 \\
Legon I & 31 & 32.3 & 67.7 \\
Total & 209 & 56.46 & 43.54 \\
\hline
\end{tabular}

\section{Insecticide susceptibility/resistance bioassay tests}

Permethrin $(0.75 \%)$ susceptibility tests of An. gambiae from eight breeding habitats in Accra showed they were highly resistant. Considerably low mortality rates of 6.5 to $20 \%$ were recorded across the eight sites. These mortality rates did not differ significantly across the eight habitats $(\mathrm{F}=1.40, \mathrm{df}=7, P=0.247)$. Mortalities in An. gambiae s.s. due to $0.05 \%$ deltamethrin ranged from 42.98 to $70.0 \%$, thus showing high level of resistance. When statistical test was carried to find out the difference in mortalities due to deltamethrin across the eight sites, no significant difference was recorded $(\mathrm{F}=1.65, \mathrm{df}=7, P=0.158)$. Generally, there were lower mortalities from permethrin as against deltamethrin (Tables 2,3).

The median knockdown time $\left(\mathrm{KDT}_{50}\right)$ obtained from time-mortality regression using Probit analysis ranged from 106.41 to $161.15 \mathrm{~min}$ while the KDT95 ranged from 158.24 to 256.50 min for permethrin. The KDT 50 for deltamethrin ranged from 43.21 to 76.36 min and KDT 95 from 72.99 to $120.97 \mathrm{~min}$. At both $\mathrm{KDT}_{50}$ and $\mathrm{KDT}_{95}$ levels, there was overlap of the $95 \%$ confidence limits for the samples from seven different breeding sites, an indication of no variation in KDT between sites for both permethrin and deltamethrin (Tables 2, 3). The response (in knockdown time) of the An. gambiae when exposed to the two insecticides is shown in Figures 1 and 2. 


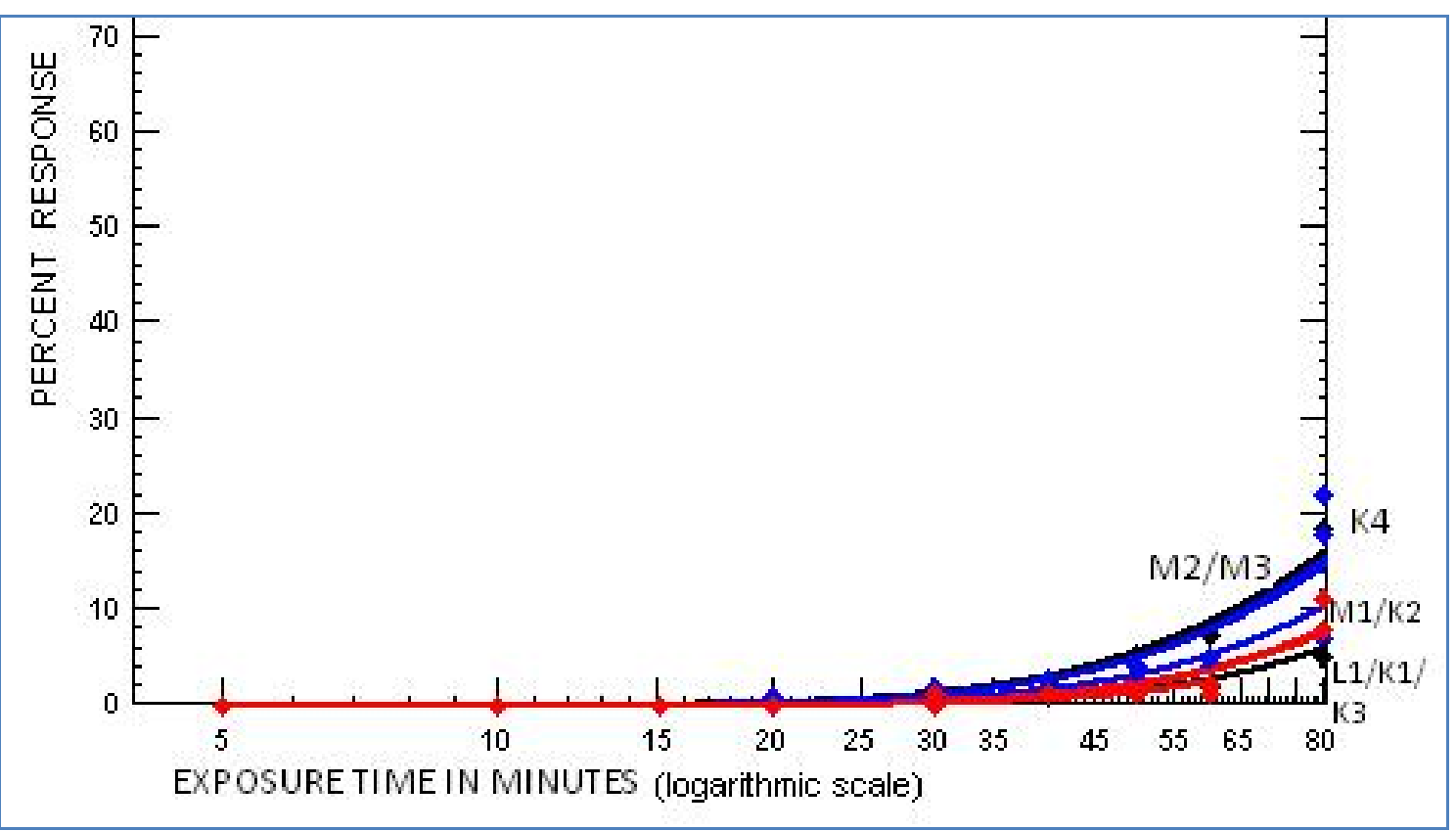

Figure 1: Probit lines showing the percentage response (knockdown time) of the Anopheles gambiae from different sampling sites after exposure to $0.75 \%$ permethrin

(K1=Korle-bu I; K2=Korle-bu II; Korle-bu III=K3; Madina III=M3; Legon I=L1; Madina I=M1; Madina II=M2; Korle-bu $\mathrm{IV}=\mathrm{K} 4)$

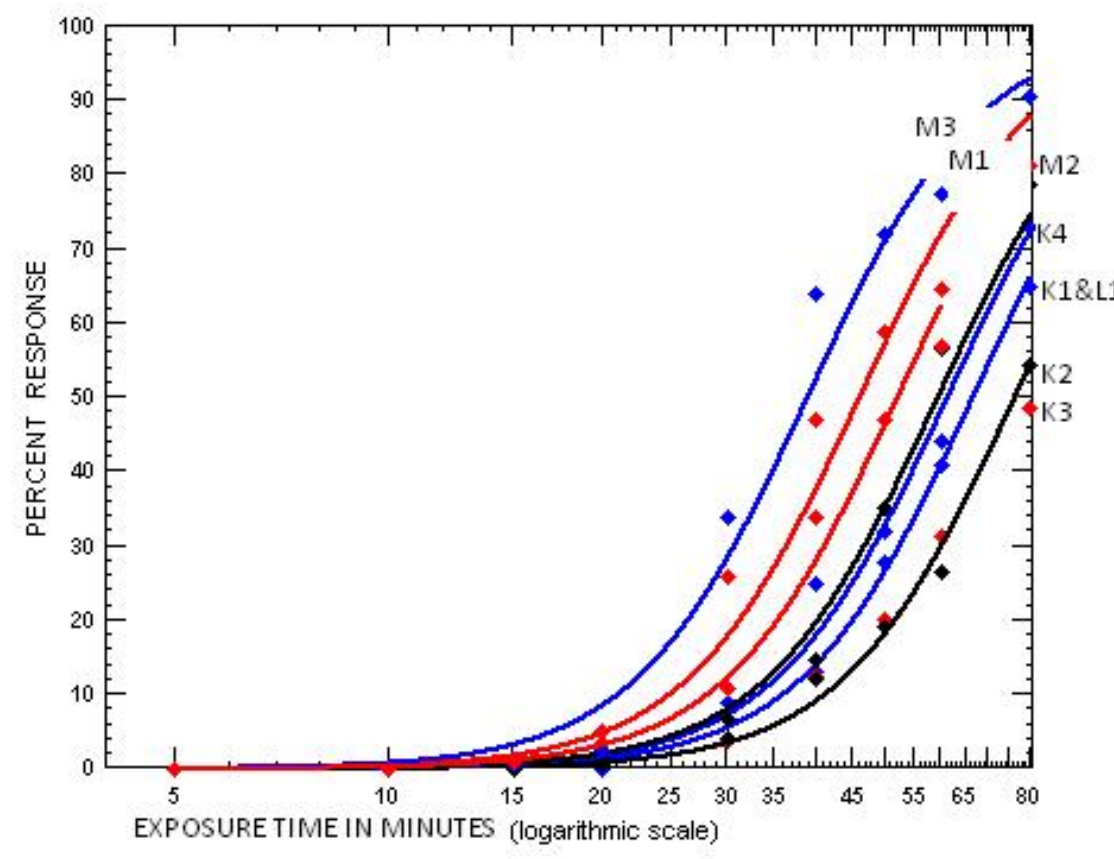

Figure 2: Probit lines showing the percentage response (knockdown time) of the Anopheles gambiae from different sampling sites after exposure to $0.05 \%$ deltamethrin 
Table 2: Knockdown time and mortality rates of An. gambiae s.l. exposed to $0.75 \%$ permethrin for a period of 60 minutes

\begin{tabular}{llllllll}
\hline Site & $\begin{array}{l}\text { No. } \\
\text { exposed }\end{array}$ & $\begin{array}{l}\text { No. } \\
\text { replicates }\end{array}$ & $\begin{array}{l}\text { Mean } \\
\text { mortality } \\
\text { (\%) } \pm \text { SD }\end{array}$ & $\begin{array}{l}\text { KDT } \\
\text { (in } \\
\text { min) }\end{array}$ & $\mathbf{9 5 \% ~ C . I . ~}$ & $\begin{array}{l}\text { KDT } 95 \\
\text { (in min) }\end{array}$ & 95\% C.I. \\
\hline Korle-bu I & 100 & 4 & $13 \pm 8.87$ & 161.15 & $124.28-265.17$ & 256.50 & $189.05-449.66$ \\
Korle-bu II & 100 & 4 & $9 \pm 5.03$ & 126.95 & $106.16-178.04$ & 186.38 & $148.10-282.77$ \\
Korle-bu III & 100 & 4 & $20 \pm 12.65$ & 159.31 & $121.16-293.75$ & 240.87 & $173.79-481.25$ \\
Korle-bu IV & 100 & 4 & $8.69 \pm 6.15$ & 106.41 & $95.01-126.13$ & 158.24 & $135.82-198.44$ \\
Legon I & 90 & 4 & $6.5 \pm 4.43$ & 139.92 & $111.48-226.37$ & 206.36 & $155.92-364.75$ \\
Madina I & 90 & 4 & $11 \pm 8.87$ & 115.63 & $99.27-156.86$ & 160.67 & $130.89-238.33$ \\
Madina II & 150 & 6 & $15.19 \pm 5.35$ & 112.47 & $98.71-137.45$ & 170.15 & $143.39-220.24$ \\
Madina III & 100 & 4 & $9 \pm 6.83$ & 109.48 & $98.71-126.42$ & 166.39 & $145.12-200.73$ \\
\hline
\end{tabular}

Table 3: Knockdown time and mortality rates of An. gambiae s.l. exposed to $0.05 \%$ deltamethrin for a period of 60 minutes

\begin{tabular}{llllllll}
\hline Site & $\begin{array}{l}\text { No. } \\
\text { exposed }\end{array}$ & $\begin{array}{l}\text { No. } \\
\text { replicates }\end{array}$ & $\begin{array}{l}\text { Mean } \\
\text { mortality } \\
(\%) \pm S D\end{array}$ & $\begin{array}{l}\text { KDT } \\
\text { (in } \\
\text { min) }\end{array}$ & $\mathbf{9 5 \% ~ C . I . ~}$ & $\begin{array}{l}\text { KDT } \\
\text { (in min) }\end{array}$ & 95\% C.I. \\
\hline Korle-bu I & 151 & 6 & $44.17 \pm 15.39$ & 67.36 & $64.59-70.55$ & 106.72 & $100.63-114.28$ \\
Korle-bu II & 80 & 4 & $55 \pm 8.72$ & 76.36 & $71.34-82.99$ & 120.97 & $109.90-136.71$ \\
Korle-bu III & 125 & 5 & $42.98 \pm 18.78$ & 75.43 & $71.53-80.25$ & 118.17 & $109.59-129.49$ \\
Korle-bu IV & 125 & 5 & $46.89 \pm 28.56$ & 62.71 & $57.74-69.15$ & 99.62 & $89.33-115.66$ \\
Legon I & 100 & 4 & $65 \pm 16.12$ & 55.66 & $51.06-61.27$ & 91.83 & $82.58-105.79$ \\
Madina I & 85 & 4 & $70 \pm 9.13$ & 50.46 & $43.34-59.77$ & 86.47 & $73.53-111.80$ \\
Madina II & 150 & 6 & $51.33 \pm 12.75$ & 59.95 & $56.63-63.79$ & 91.63 & $84.99-100.72$ \\
Madina III & 150 & 6 & $66.67 \pm 24.61$ & 43.21 & $35.49-52.46$ & 72.99 & $61.29-98.16$ \\
\hline
\end{tabular}

C.I. =Confidence Interval, $\mathbf{S D}=$ standard deviation, KDT=Knockdown time

$\mathrm{KDT}_{50}=$ time taken for $50 \%$ of the test mosquitoes to be knocked down, $\mathrm{KDT}_{95}=$ time taken for $95 \%$ of the test mosquitoes to be knocked down 
Distribution of the kdr Allele in An. gambiae s.s. population

A total of 195 An. gambiae s.s. were analysed for $k d r$ mutation. Of these, 118 (60.50\%) were found to have the $k d r$ mutation. The $k d r$ mutation was present in $56(50.45 \%)$ in the M-form and 62 $(73.81 \%)$ in the S-form. Across the eight sites, higher $k d r$ frequencies were recorded in Smolecular forms as compared to M-molecular forms and the relationship between molecular forms and $k d r$ frequency were highly significant $\left(X^{2}=10.92, \mathrm{df}=1, P=0.001\right)$. In the $\mathrm{M}$-form the $k d r$ mutation was present in 45 (63.60\%) at Korle-bu sampling sites and 11 (25.25\%) at Madina and Legon sites. In the S-form it was present in 16 (90.18\%) at Korle-bu sampling sites and 46 $(72.8 \%)$ at Madina and Legon sites. The $k d r$ frequencies in the M-form were significantly associated with Korle-bu sampling sites $\left(X^{2}=10.69, \mathrm{df}=1, P=0.001\right)$ while in the S-form the association with sampling sites were not significant $\left(X^{2}=2.69, \mathrm{df}=1, P=0.135\right)$. The allelic frequency distribution of $k d r$ mutation by site and molecular forms are shown in Table 4 .

Table 4: Frequency distribution (in percentage) of the $k d r$ allele mutations in the studied An. gambiae s.s. molecular forms

\begin{tabular}{|c|c|c|c|c|c|c|}
\hline \multirow{3}{*}{ Site } & \multirow{3}{*}{$\mathbf{n}$} & \multirow{3}{*}{$\begin{array}{l}\text { Total } k d r \\
\text { frequency (\%) }\end{array}$} & \multicolumn{4}{|c|}{$k d r$ frequency $(\%)$ by molecular forms } \\
\hline & & & \multicolumn{2}{|c|}{ M-form } & \multicolumn{2}{|l|}{ S-form } \\
\hline & & & $K d r+v e$ & $K d r$-ve & $k d r+\mathrm{ve}$ & $K d r$-ve \\
\hline Korle-bu I & 25 & 76 & 71.43 & 28.57 & 100 & 0 \\
\hline Korle-bu II & 19 & 63.16 & 66.25 & 33.75 & 100 & 0 \\
\hline Korle-bu III & 23 & 60.87 & 57.89 & 42.11 & 75 & 25 \\
\hline Korle-bu IV & 24 & 66.67 & 58.82 & 41.18 & 85.7 & 14.3 \\
\hline Madina I & 27 & 55.56 & 40 & 60 & 75 & 25 \\
\hline Madina II & 19 & 63.16 & 14.29 & 85.71 & 91.7 & 8.3 \\
\hline Madina III & 28 & 46.43 & 16.7 & 83.3 & 54.5 & 45.5 \\
\hline Legon I & 30 & 56.57 & 30 & 70 & 70 & 30 \\
\hline Total & 195 & 60.51 & 50.45 & 49.55 & 73.81 & 26.19 \\
\hline
\end{tabular}

Physicochemical parameters of An. gambiae s.l. breeding habitats

A total of 29 parameters of water comprising of 13 physical and 16 chemical were measured from the total of eight water samples collected from eight breeding sites (Table 5). These breeding sites were from three sampling areas namely Korle-bu, Madina and Legon. Turbidity was higher (>1000 NTU) for the Korle-bu sampling sites, moderate (340-663 NTU) in Madina and Legon, and lower (10-40 NTU) for those at Madina sites II and III. There was significant variation in turbidity among these three sampling areas $(\mathrm{F}=48.749, \mathrm{df}=2, P=0.001)$. Water $\mathrm{pH}$ values ranged from 8.8 to 9.4 (Mean=9.163) at Korle-bu and 7.1 to 8.4 (Mean=7.598) at Madina and Legon. These $\mathrm{pH}$ values also varied significantly among the three sampled areas $(\mathrm{F}=11.575$, $\mathrm{df}=2, P=0.013$ ). Similarly, temperature values ranged from $31-40^{\circ} \mathrm{C}$ (Mean $=34.75^{\circ} \mathrm{C}$ ) and they varied significantly among the three sampled areas $(\mathrm{F}=11.843, \mathrm{df}=2, P=0.013)$. The only chemical parameter of water which varied significantly among the three sampling areas was carbonate $(\mathrm{F}=11.343, \mathrm{df}=2, P=0.014)$. The carbonate concentration in these sampling areas ranged from 0 $14.2 \mathrm{mg} / \mathrm{l}$ with the mean of $5.31 \mathrm{mg} / \mathrm{l}$. There were no significant differences (ANOVA, $P>0.05$ ) among the three sampling areas in respect of the other 15 chemical and 10 physical parameters tested. 
Physicochemical parameters of water for Madina III sampling site, which was taken as an example of a typical breeding site for Anopheles mosquitoes, were also compared with those from the other seven breeding habitats. This breeding habitat recorded low levels of the following; turbidity of $10 \mathrm{NTU}$, pH was 7.1, total suspended solids (TSS) was $7 \mathrm{mg} / \mathrm{l}$, dissolved oxygen (DO) was $5.8 \mathrm{mg} / \mathrm{l}$, biological oxygen demand (BOD) was $16 \mathrm{mg} / \mathrm{l}$, ammonium concentration was $<0.005 \mathrm{mg} / \mathrm{l}$, phosphate was $<0.005 \mathrm{mg} / \mathrm{l}$ and nitrite was $<0.005 \mathrm{mg} / \mathrm{l}$. There were however no significant differences (ANOVA, $P>0.05$ ) with the other seven breeding sites. Madina III also recorded significantly $(\mathrm{F}=12.688, \mathrm{df}=1, P=0.012)$ high value of conductivity of $14,000 \mathrm{u} S / \mathrm{cm}$. Similary, water parameters that correlated positively with conductivity, also recorded significantly higher values at this site (Madina III) compared to those of the other seven sampling sites. These were TDS $(\mathrm{F}=27.922, \mathrm{df}=1, P=0.002)$, total water hardness $(\mathrm{F}=2384.388, \mathrm{df}=1, P=0.000)$, calcium hardness $(\mathrm{F}=2326.292, \mathrm{df}=1, P=0.000)$, magnesium hardness $(\mathrm{F}=1442.627, \mathrm{df}=1, P=0.000)$, sodium $(\mathrm{F}=67.540, \mathrm{df}=1, P=0.000)$, potassium $(\mathrm{F}=10.241, \mathrm{df}=1$, $P=0.019)$, calcium $(\mathrm{F}=2349.207, \mathrm{df}=1, P=0.000)$, magnesium $(\mathrm{F}=1439.934, \mathrm{df}=1, P=0.000)$, chloride $(\mathrm{F}=119.959, \mathrm{df}=1, P=0.000)$, sulphate $(\mathrm{F}=39.503, \mathrm{df}=1, P=0.001)$ and bicarbonates $(\mathrm{F}=149.269, \mathrm{df}=1$, $P=0.000)$.

The principal component analysis (PCA) was used to examine the relationships (interaction effects) among all 29 physicochemical parameters of water. The first three components (PC1, PC2, PC3) cumulatively explained $86.1 \%$ of the variation observed among the different mosquito breeding habitats. Sulphate, sodium, TDS, chloride, conductivity, potassium, bicarbonates, calcium, magnesium, total alkalinity and water hardness (total hardness, calcium hardness and magnesium hardness) contributed the most to explain the variation in the first component. Carbonate, $\mathrm{pH}$, turbidity, $\mathrm{DO}$, temperature and fluoride contributed the most to explain the variation in the second component; and Nitrite, COD, TSS, BOD and manganese in the third component.

\section{Physicochemical parameters of breeding habitats and distribution of An. gambiae s.s. molecular forms}

The bivariate correlation procedure computed using Pearson's correlation coefficient revealed that the higher proportions of An. gambiae s.s. M-form in larval habitats were significantly and positively correlated with temperature $(\mathrm{r}=0.728, P=0.041)$, turbidity $(\mathrm{r}=0.861, P=0.006), \mathrm{pH}$ ( $\mathrm{r}=0.994, P=0.000)$, ammonium $(\mathrm{r}=0.847, P=0.008)$, phosphate $(\mathrm{r}=0.813, P=0.014)$, fluoride ( $\mathrm{r}=0.739$, $P=0.036)$, carbonate $(\mathrm{r}=0.914, P=0.001)$ and dissolved oxygen $(\mathrm{r}=0.856, P=0.007)$. All these water parameters, significantly and negatively correlated (with the same values of $\mathrm{r}$ and $p$ as that of $\mathrm{M}$ form) to the higher proportions of An. gambiae s.s. S-form.

Multiple regression analysis was further performed on the significantly correlated parameters to select the best predictors of high proportions of An. gambiae s.s. M-form. The $\mathrm{pH}$ and carbonate were selected as the best predictors in the model $(P=0.001)$. These together accounted for $91.3 \%$ of the total variation observed. This was further confirmed by stepwise discriminant function analysis, where $\mathrm{pH}$ and carbonate were still the best discriminatory parameters between high/low proportion of $A n$. gambiae s.s. M-form larval habitats $(P=0.001)$. To determine which of the non-selected parameters were associated with $\mathrm{pH}$ and carbonate, and thus acting as indirect predictors of proportions of An. gambiae s.s. M-form, multiple regression analyses were performed using these as dependent variables. The analysis revealed that DO, 
fluoride and temperature were the best variables, together accounting for $97.2 \%$ of the variation existing in $\mathrm{pH}$. Turbidity and total iron were the best variables associated with carbonate, together accounting for $93.4 \%$ of the variation observed in carbonate.

Physicochemical parameters of water and distribution of pyrethroid resistance and kdr allele in An. gambiae s.s.

The bivariate correlation procedure computed using Pearson's correlation coefficient revealed that resistance of An. gambiae s.s. to deltamethrin was significantly correlated with ammonium (r=0.754, $P=0.031)$ and fluoride $(\mathrm{r}=0.910, \quad P=0.002)$; while resistance to permethrin was significantly correlated with TSS $(r=-0.754, p=0.031)$, ammonium $(r=-0.745, P=0.034)$ and nitrate $(\mathrm{r}=-0.783, P=0.022)$. Follow up multiple regression analysis performed on these parameters to select the best predictors of resistance selected fluoride $\left(\mathrm{R}^{2}=0.829, \mathrm{~F}=28.99, P=0.002\right)$ and nitrite $\left(\mathrm{R}^{2}=0.613, \mathrm{~F}=9.52, P=0.022\right)$ as best predictors for deltamethrin and permethrin resistance respectively.

The frequency of $k d r$ mutation gene correlated with fluoride ( $\mathrm{r}=0.731, P=0.039$ ). Discriminant function analysis was performed where all $k d r$ frequencies of more than $50 \%$ were classified as " $k d r+v e$ " and frequency of $50 \%$ and below as " $k d r$-ve". This analysis revealed that total hardness and silica were the best discriminatory parameters between " $k d r+v e^{\prime \prime} /$ " $k d r$-ve" in An. gambiae s.s. larval habitats $(P=0.000)$. 
Table 5: Physical and chemical parameters of water recorded at the eight sampling sites

\begin{tabular}{|c|c|c|c|c|c|c|c|c|}
\hline \multirow[b]{2}{*}{ Parameter(unit) } & \multicolumn{8}{|c|}{ Sampling sites } \\
\hline & Korle-bu I & Korle-bu II & Korle-bu III & Korle-bu IV & Madina I & Madina II & Madina III & Legon I \\
\hline \multicolumn{9}{|l|}{ Physical parameters } \\
\hline Turbidity(NTU) & $>1000$ & $>1000$ & $>1000$ & $>1000$ & 340 & 40 & 10 & 663 \\
\hline Temperature $\left({ }^{\circ} \mathrm{C}\right)$ & 37 & 36 & 36 & 40 & 32 & 32 & 31 & 34 \\
\hline $\mathrm{pH}$ (pH units) & 9.24 & 9.44 & 9.22 & 8.75 & 8.37 & 7.61 & 7.1 & 7.31 \\
\hline Total alkalinity (mg/l) & 620 & 420 & 1206 & 3575 & 2290 & 740 & 3600 & 72 \\
\hline Conductivity(ųS/cm) & 7630 & 6440 & 7260 & 4350 & 4960 & 3290 & 14000 & 979 \\
\hline Total suspended solids(mg/l) & 3720 & 2540 & 16360 & 1648 & 215 & 25 & 7 & 1232 \\
\hline Total dissolved solids(mg/l) & 6230 & 3710 & 5090 & 2802 & 3095 & 2065 & 13503 & 968 \\
\hline Total hardness (mg/l) & 440 & 490 & 620 & 525 & 600 & 630 & 6000 & 346 \\
\hline Calcium hardness (mg/l) & 218 & 218 & 305 & 200 & 220 & 261 & 2104 & 218 \\
\hline Magnesium hardness (mg/l) & 222 & 272 & 315 & 324.6 & 379.6 & 370 & 3896 & 128 \\
\hline Dissolved oxygen $(\mathrm{mg} / \mathrm{l})$ & 9.6 & 9.8 & 8.8 & 7.4 & 9.4 & 6.1 & 5.8 & 6.4 \\
\hline${ }^{*}$ Biological $\mathrm{O}_{2}$ demand $(\mathrm{mg} / \mathrm{l})$ & 42 & 36 & 180 & 64 & 57 & 34 & 16 & 20 \\
\hline${ }^{*} \mathrm{Chemical} \mathrm{O}_{2}$ demand $(\mathrm{mg} / \mathrm{l})$ & 538 & 346 & 2074 & 314 & 366 & 81 & 162 & 186 \\
\hline \multicolumn{9}{|l|}{ Chemical parameters } \\
\hline Sodium $(\mathrm{mg} / \mathrm{l})$ & 995 & 810 & 1105 & 570 & 270 & 410 & 3900 & 109 \\
\hline Potassium (mg/l) & 102 & 90 & 96 & 65 & 50 & 30 & 180 & 15 \\
\hline Calcium (mg/l) & 87.4 & 87.4 & 122 & 80 & 88 & 104 & 842 & 87 \\
\hline Magnesium (mg/l) & 53.8 & 66 & 76.6 & 78.9 & 92 & 90 & 947 & 31 \\
\hline Total iron $(\mathrm{mg} / \mathrm{l})$ & 0.256 & 0.116 & 0.323 & 2 & 2.28 & 1.08 & 0.178 & 2.68 \\
\hline Ammonium (mg/l) & 11.4 & 7.96 & 16 & 6.2 & 5.84 & 4.92 & $<0.005$ & 3.08 \\
\hline Chloride (mg/l) & 1589 & 1260 & 1637 & 893 & 367 & 566 & 7494 & 310 \\
\hline Sulphate (mg/l) & 128 & 121 & 158 & 105 & 101 & 85 & 340 & 48 \\
\hline Phosphate (mg/l) & 3.32 & 1.84 & 3.16 & 0.594 & 1.99 & 0.23 & $<0.005$ & 0.129 \\
\hline Manganese (mg/l) & 0.666 & 0.109 & 0.721 & 0.248 & 0.118 & 0.086 & 0.146 & 0.244 \\
\hline Nitrite $(\mathrm{mg} / \mathrm{l})$ & 0.229 & 0.388 & 20.005 & 1.19 & 0.386 & 0.846 & $<0.005$ & 0.481 \\
\hline Nitrate (mg/l) & 4.79 & 9.84 & 1.07 & 7.62 & 4.95 & 8.25 & 1.16 & 1.43 \\
\hline Fluoride (mg/l) & 1.65 & 1.59 & 1.60 & 1.31 & 0.328 & 1.37 & 0.574 & 0.213 \\
\hline Bicarbonate (mg/l) & 756 & 512 & 747 & 748 & 897 & 903 & 4392 & 88 \\
\hline Carbonate (mg/l) & 12.6 & 14.2 & 10.8 & 4.88 & 0 & 0 & 0 & 0 \\
\hline Silica (mg/l) & 18.1 & 22.8 & 16.5 & 19.6 & 10.8 & 15.8 & 21.6 & 28.3 \\
\hline
\end{tabular}

*These are also referred to as Biological Parameters of water 


\section{Discussion}

In this study An. gambiae s.s. was the only member of the An. gambiae complex found in the study area. This finding is consistent with earlier studies in the grater Accra Region (Appawu, 2001; Midega, 2001; Adeniran, 2002; Sibomana, 2002; Otieno, 2004; Achonduh, 2005). The two molecular forms of An. gambiae s.s. were sympatric in all eight sampling sites. This results agree with surveys in Mali, where $\mathrm{M}$ and $\mathrm{S}$ forms were sympatric in many larval sites (Edillo et al., 2002), as was the case for An. gambiae s.s. and An. arabiensis in Kenya (Gimnig et al., 2001). However, sympatry does not necessarily mean that the two forms have the same ability to exploit these shared habitats. This can be clearly shown by difference in their proportions in the breeding sites. The M-form predominated all Korle-bu sampling sites and Madina I while the Sform predominated the rest of sites at Madina and Legon. Korle-bu is low laying area that is normally flooded during rain season and is popularly used for irrigated urban vegetable farming all the year round. The $\mathrm{M}$ form may therefore have predominated Korle-bu probably due to the proximity of the permanent breeding conditions provided by urban agriculture. The $\mathrm{M}$ form of An. gambiae is known to be associated with urban environment and flooded/irrigated sites, typified by extensive cultivation, whereas the $S$ form is characteristically found in temporary, rain-dependent breeding sites (Toure' et al., 1998; Diabate' et al., 2003). No hybrid $\mathrm{M} / \mathrm{S}$ form individuals were detected in any of the collection sites, although low levels of hybridization between $\mathrm{M}$ and $\mathrm{S}$ molecular forms have been reported to occur elsewhere (della Torre et al., 2001; Tripét et al. 2001; Taylor et al., 2001). The lack hybrid M/S form in this study were consistent with previous studies in Cameroon, Ghana and Angola (Wondji et al., 2002; Yawson et al., 2004; Cuamba et al., 2006). This lack of M/S hybrids in the field is hypothesized to be due to partial reproductive isolation among molecular forms, with gene flow occurring only in certain geographical locations or at certain seasons (Black \& Lanzaro, 2001).

Susceptibility test results generally showed high levels of resistance to both deltamethrin and permethrin in the field populations of An. gambiae. At all sites, the populations of $A n$. gambiae tested showed high levels of resistance to deltamethrin and higherlevels to permethrin. This high level of resistance recorded in this study is strongly supported by increased median knockdown time (KDT50) as compared to the previous study done in Accra (Achonduh, 2005). Higher KDT50 values in the field population have been suggested to give an early indication of the involvement of $k d r$ mechanism of resistance (Chandre et al., 1999a,b). Generally, these results are consistent with those of other studies conducted in Accra (Adasi et al., 2000; Adeniran, 2002; Achonduh, 2005) and in Volta Region (Kahindi, 2005), where An. gambiae s.l. has been reported to be resistant to pyrethroids and DDT.

The PCR analysis to detect the molecular basis of insecticide resistance revealed high frequency of the $k d r$ gene mutation. The observed high frequency of resistant phenotype of $k d r$ is supported by the high increase in knockdown times in field populations. This high $k d r$ frequency by no means accounts for the very low mortalities observed in field populations with permethrin and deltamethrin. These results also agree with previous studies in Accra (Adasi et al., 2000; Adeniran, 2002; Achonduh, 2005) and Volta Region (Kahindi, 2005) of Ghana. The $k d r$ gene mutations occurred in both $\mathrm{S}$ and $\mathrm{M}$ forms, but it was found to be mainly associated and at high frequencies in the $S$ form. This high frequency of $k d r$ mutations in $S$ form and its low/absence in the $\mathrm{M}$ has also been reported in previous studies in Ghana (Yawson et al., 2004), 
Burkina Faso (Diabate et al., 2003; Yawson et al., 2004), Côte d'Ivoire (della Toure et al., 2001), Nigeria (Awolola et al., 2003) and Mali (Fanello et al., 2002). In Benin, Corbel et al. (2004) recorded high $k d r$ frequencies in $\mathrm{M}$ form where as, in this study high $k d r$ frequencies in $\mathrm{M}$ form were recorded at Korle-bu sampling sites. Also these $k d r$ frequencies in the M-form registered significant association with Korle-bu sampling sites and not with other sites. What exactly causes this spatial variation in $k d r$ frequencies in the $\mathrm{M}$ form is could not be determined. It has been postulated that the $k d r$ mutation reached the $\mathrm{M}$ form through introgression from the $\mathrm{S}$ form (Weill et al., 2000), although further work will be necessary to determine if this has occurred in our local study populations (Yawson et al., 2004).

Larvae of An. gambiae s.l. normally inhabit diverse small water bodies that are often numerous, scattered, sunlit, turbid, temporary, and close to human dwellings (Gimnig et al., 2001). These habitats differ in physical as well as biological characteristics, which directly influence the distribution and abundance of larval mosquito populations in nature. In this study, of the 29 water parameters measured, only turbidity, $\mathrm{pH}$, temperature and carbonate differed significantly among three sampling areas (Madina, Legon and Korle-bu). Differences in water quality in these three different areas may be due to influence by rock and soil chemistry, and human activities. On the other hand, the low levels of ammonium, nitrite, turbidity, phosphate, TSS, BOD and DO recorded at Madina III sampling site which in this case was regarded as a typical breeding site (control) for An. gambiae, is an indication of low level of pollution at this site. Thus to say, high levels of these water parameters in the other sampled habitats (especially those at Korle-bu and Madina I), is a good indication of high level of pollution at these sites.

In this study the immatures of An. gambiae s.s. $\mathrm{M}$ form habitats were associated with turbidity, $\mathrm{pH}$, temperature, DO, ammonium, phosphate, fluoride and carbonate. In breeding sites with high values of these parameters, high proportion of $\mathrm{M}$ form were much more likely to be recorded, whereas $S$ form larvae were much more likely to be in low proportion. The association of An. gambiae s.s. M form habitats with high levels of ammonium, which is one of the main determinants of water pollution, is a clear indication of its adaptation to breed in polluted water. However multivariate factor analysis selected only $\mathrm{pH}$ and carbonate as the major variables that determine the high proportion of $\mathrm{M}$ form. In contrast, studies in Mali by Edillo et al. (2006) did not detect any associations between the species or molecular forms and any physicochemical variables of water, except conductivity and TDS.

The $\mathrm{pH}$ of water is dependent on the concentrations of anions, cations, salts and synthetic compounds which indicate its acidic or basic character (Bos, 1991). Therefore, it may be direct or indirect determinant of any aquatic life. Apart from direct effect which is not clearly known, anions and cations may also indirectly affect mosquito breeding by favouring certain types of aquatic vegetation or organisms on which mosquito larvae feed or by affecting potential biological control agents of mosquito larvae (Bos, 1991). Further analysis indicated that $\mathrm{DO}$, fluoride and temperature were the main variables contributing to the variation in $\mathrm{pH}$, while turbidity and total iron were the main factors for the variation in carbonate. This indicates that these parameters have indirect effects on the suitability of a habitat for these two molecular forms. For example optimum temperature is said to be important for microbial growth upon which mosquito larvae depend on (Ramachandra Rao, 1984). 
Though not basing on molecular forms of An. gambiae, studies elsewhere supports this findings as they recorded association between water turbidity and breeding habitats for $A n$. gambiae (Gimnig et al., 2001; Sibomana, 2002; Ye-Ebiyo et al., 2003). However, the simple definition of "turbidity" which favours Anopheles larvae in a habitat might not be precise enough. This is because water which is turbid from particles not nutritious for Anopheles larvae could disfavour the growth and development of larvae, while water turbid from food particles represents a very suitable habitat. In a study by Reisen et al. (1981), DO and $\mathrm{pH}$ were the major variables in Anopheles breeding habitats. However, the role of DO as a potentially significant variable as found in several studies is interesting and needs further exploration. Mosquito larvae are air-breathing, and this raises the question as to whether it is oxygen per se, or an associated physico-chemical or biotic factor that influences the occurrence and abundance of this species.

It is speculated that the $\mathrm{M}$ and $\mathrm{S}$ forms contrast significantly in their way of exploiting limiting resources in their habitats (della Torre et al., 2002). This is shown in the current study and is consistent with a study by Diabate et al. (2005). Diabate et al. (2005) suggested that both forms successfully exploit different habitats with regard to the chemical, physical, and microbiological conditions. However it is possible that the forms differ in utilizing these limiting resources along with other variables not measured, but are known to influence the suitability of certain water bodies for An. gambiae s.l. breeding. These include bacterial composition (Gimnig et al., 2002), chlorophyll (Gimnig et al., 2002; Mwangangi et al., 2007), detritus (Merritt et al., 1992), and maize pollen (Ye-Ebiyo et al., 2003).

This study showed that the occurrence of deltamethrin resistance to An. gambiae was positively associated with ammonium and fluoride. It also showed that permethrin resistance was negatively associated with TSS, ammonium, and nitrate and that fluoride and nitrite were selected as the best predictors for deltamethrin and permethrin resistance respectively. Since ammonium level (>1 mg/l) is an indication of how polluted the site is, it can be said that, resistance of An. gambiae to deltamethrin is an influencing factor for their breeding in this polluted water. Though nitrites and fluoride were found as predictors of pyrethroid resistance, the mechanisms underlying the influence of these water parameters in the occurrence of pyrethroid resistance and/or the influence of pyrethroid resistance on adaptation of An. gambiae to polluted habitats are not well understood and needs further exploration.

Total hardness and silica were the best discriminatory parameters of "kdr+"/kdr-" in $A n$. gambiae s.s. larval habitats. Total water hardness is affected by other factors such as TDS, conductivity, $\mathrm{Na}, \mathrm{K}, \mathrm{Ca}, \mathrm{Mg}, \mathrm{Cl}, \mathrm{SO}_{4}$, and $\mathrm{HCO}_{3}$. However the involvement of these water parameters in the occurrence of $k d r$ mutation gene in An. gambiae is not well understood and need to be studied. Apart from physicochemical properties of breeding habitats determined in this study, other factors such as insecticide residue in water and soil, may have contributed to the occurrence of both pyrethroid resistance and $k d r$ mutation in An. gambiae population. Thus, apart from water parameters, the pyrethroid resistance observed in this study could be due to the selection pressure resulting from continuous exposure to insecticides used in both public health (Adasi et al., 2000) and urban agriculture (Achonduh, 2005).

Currently, the most advocated worldwide malaria vector control strategy appears to be the use of insecticide (pyrethroid) - treated nets (ITN). The evolution of pyrethroid resistance poses a threat to this strategy. In this study, resistance was generally high against deltamethrin 
and permethrin, which are commonly used for impregnating bednets and curtains as well as indoor residual spraying against mosquitoes. This could have serious implications in malaria transmission as well as compliance to ITN programmes. It has already been pointed out that any failure in nuisance control due to resistance is likely to demotivate people in using impregnated materials (Chandre et al., 1998). However to compromise vector control with insecticides, the level of resistance must be high enough to adversely affect disease transmission and in many cases, vector control may not be affected by the observed levels of resistance in the vectors (Brogdon \& McAllister, 1998). Even in areas of high pyrethroid resistance and high $k d r$ gene frequency in An. gambiae, deltamethrin treated mosquito nets remain effective in vector control and should still be considered as a practical means of personal protection against malaria (Darriet et al., 2000). Thus in this situation, increasing surveillance and monitoring level and frequency of resistance would be sufficient before the need for considering change in control methods.

The adaptation of An. gambiae in polluted aquatic habitats coupled with occurrence of insecticide resistance is quite alarming especially for urban malaria control. This adaptation may lead to the occurrence of malaria transmission throughout the year as opposed to its normal seasonal transmission pattern in urban settings as a result of abundance of their suitable breeding habitats created by urbanization which occurs in many parts throughout the year. Although these finding seems to indicate a difference in aquatic habitat usage between molecular forms of An. gambiae s.s., it does not suggest that the spatial segregation between them is determined by larval adaptations to different habitats. Findings from this study suggest that adaptation of $A n$. gambiae s.s. to breed in polluted water may be influenced by their insecticide resistance status and vice versa. However, these findings should be considered preliminary because this is the first study relating physicochemical properties of water and insecticide resistance in the urban settings and that it involved few sampling sites. Thus it is recommended that a similar study be carried out on a larger sample size within urban Accra and in similar cities in Africa. Other factors in mosquito larvae habitats which may have influence on insecticide resistance such as insecticides residues levels should be investigated together with physicochemical properties of water. Since mosquito diverse larval diets and habitats have an influence on the development of extensive families of detoxification enzymes as an adaptive response in mosquitoes which in turn may influence their ability to withstand insecticides, it is recommended that such a study be carried out to ascertain enzyme activity profiles in relation to physical, chemical and biological parameters of water. Also other environmental factors such as bacterial composition, chlorophyll, detritus, and maize pollens may influence the suitability of certain water bodies for An. gambiae breeding together with physical and chemical parameters of water quality, and may need to be explored.

\section{Acknowledgements}

We are grateful to the Deutscher Akademischer Austausch Dienst e.v. (DAAD) through the African Regional Postgraduate Programme in Insect Science (ARPPIS) and NMIMR for funding the study. We are also grateful to Professor Prof Alex Nyarko, Director of NMIMR for his permission to carry out and use the facilities of the Institute. Our thanks also go Mr. Isae Sibomana, Kojo Sakyi and Dr. Charles A. Brown for their technical laboratory assistance.We 
would like to thank the staff of analytical laboratory of the Water Research Institute for their immense help in water analyses.

\section{References}

Abbott, W.S. (1925) A method of computing the effectiveness of an insecticide. Journal of Economic Entomology 18, 265-267.

Achonduh, O.A. (2005) Insecticide resistance in Anopheles gambiae s.l. Giles (Diptera: Culicidae) in cabbage growing areas associated with pyrethroid and organophosphate use in Accra, Ghana. MPhil Entomology Thesis, University of Ghana, Legon.

Adasi, K., Wilson, M.D. \& Boakye, D.A. (2000) Studies on insecticide usage and pyrethroid resistance in populations of An. gambiae s.s (Diptera; Culicidae) in the Greater Accra Region of Ghana. WHO-MIM Conference on Insecticide Resistance, Harare, Zimbabwe.

Adeniran, T.A. (2002) Studies on insecticide usage and pyrethroid resistance in populations of Anopheles gambiae s.s (Diptera: Culicidae) in the Greater Accra Region of Ghana, MPhil Entomology Thesis, University of Ghana, Legon.

Afrane, Y.A., Klinkenberg, E., Drechsel, P., Owusu-Daaku, K., Garms, R. \& Kruppa, T. (2004) Does irrigated urban agriculture influence the transmission of malaria in the city of Kumasi, Ghana? Acta Tropica 89, 125-134.

Akogbeto, M. (1995) Entomological study on the malaria transmission in coastal and lagoon areas: the case of a village built on a brackish lake. Annales de la Société Belge de Médecine Tropicale 75, 219-227.

American Public Health Association, American Water Works \& Water Environment Federation (1998) Standard Methods for the Examination of Water and Wastewater. $20^{\text {th }}$ ed. United Book Press, Inc., Baltimore, Maryland.

Appawu, M.A., Baffoe-Wilmot, A., Afari, E.A., Dunyo, S., Koram, K.A. \& Nkrumah, F.K. (2001) Malaria vector studies in two ecological zones in southern Ghana. African Entomologist 9, 59-65

Awolola, T.S., Brooke, B.D., Koekemoer, L.L. \& Coetzee, M. (2003) Absence of the $k d r$ mutation in the molecular ' $\mathrm{M}$ ' form suggests different pyrethroid resistance mechanisms in the malaria vector mosquito Anopheles gambiae s.s. Tropical Medicine and International Health $8,420-422$.

Black, W.C. \& Lanzaro, G.C. (2001) Distribution of genetic variation among chromosomal forms of Anopheles gambiae s.s: introgressive hybridization, adaptive inversions, or recent reproductive isolation? Insect Molecular Biology 10, 3-7.

Bos, R. (1991) Water Quality, Disease and Human Health. Paper presented at the Water Quality Conference, Bratislava.

Briegel, H. (2003) Physiological bases of mosquito ecology. Journal of Vector Ecology 28, 1-11.

Brogdon, W.C. \& McAllister, J.C. (1998) Insecticide resistance and vector control. Emerging Infectious Diseases 4, 605-613.

Budiansky, S. (2002) The mosquito genome: Anopheles gambiae. Creatures of our own making. Science 298, 80-86. 
Chandre, F., Darriet, F., Darder, M., Cuany, A., Doannio, J.M.C., Pasteur, N. \& Guillet, P. (1998) Pyrethroid resistance in Culex quinquefasciatus from West Africa. Medical and Veterinary Entomology 12, 359-366.

Chandre, F., Darriet, F., Manguin, S., Brengues, C., Carnevale, P. \& Guillet, P. (1999a) Pyrethroid cross resistance spectrum among populations of Anopheles gambiae s.s from Côte D'Ivoire. Journal of American Mosquito Control Association 15, 53-59.

Chandre, F., Manguin, S., Brengues, C., Dossou Yovo, J., Darriet, F., Diabate, A., Carnevale, P. \& Guillet, P. (1999b) Current distribution of a pyrethroid resistance gene $(k d r)$ in Anopheles gambiae complex from West Africa and further evidence for reproductive isolation of the Mopti form. Parassitologia 41, 319-322.

Collins, F.H., Mendez, M.A., Razmussen, M.O., Mehaffey, P.C., Besansky, N.J. \& Finnerty, V. (1987) A ribosomal RNA gene probe differentiates member species of Anopheles gambiae complex. American Journal of Tropical Medicine and Hygiene 37, 37- 41,

Corbel, V. Chandre, F. Brengues, C., Akogbeto, M., Lardeux, F., Hougard, J. M. \& Guillet, P. (2004) Dosage-dependent effects of permethrin-treated nets on the behaviour of Anopheles gambiae and the selection pyrethroid resistance. Malaria Journal 3:22.

Cuamba, N., Choi, K.S. \& Townson, H. (2006) Malaria vectors in Angola: distribution of species and molecular forms of the Anopheles gambiae complex, their pyrethroid insecticide knockdown resistance (kdr) status and Plasmodium falciparum sporozoite rates. Malaria Journal 5: 2.

Darriet, F., N'guessa, R., Koffi, A.A., Konan, L., Doannio, J.M., Chandre, F. \& Carnevale, P. (2000) Impact of pyrethrin resistance on the efficacy of impregnated mosquito nets in the prevention of malaria: results of test in experimental cases with deltamethrin SC. Bulletin de la Societe de Pathologie Exotique 93, 131-134.

della Torre, A., Costantini, C., Besansky, N.J., Caccone, A., Petrarca, V., Powell, J.R. \& Coluzzi, M. (2002) Speciation within Anopheles gambiae - the glass is half full. Science 298, 115117.

della Torre, A., Fanello, C., Akogbeto, M., Dossou-Yovo, J., Favia, G., Petrarca, V. \& Coluzzi, M. (2001). Molecular evidence of incipient speciation within Anopheles gambiae s.s. in west Africa. Insect Molecular Biology 10: 9-18.

Diabate, A., Baldet, T., Chandre, C., Dabiré, K.R., Kengne, P., Guiguemdé, T.R., Simard, F., Guillet, P., Hemingway, J. \& Hougard, J.M. (2003) KDR mutation, a genetic marker to assess events of introgression between the molecular $\mathrm{M}$ and $\mathrm{S}$ forms of Anopheles gambiae (Diptera: Culicidae) in the tropical savannah area of West Africa. Journal of Medical Entomology 40, 195-198.

Diabate,' A., Dabiré, R.K., Kim, E.H., Dalton, R., Millogo, N., Baldet, T., Simard, F., Gimnig, J. E., Hawley, W.A. \& Lehman, T. (2005) Larval development of the molecular forms of Anopheles gambiae (Diptera: Culicidae) in different habitats: A transplantation experiment. Journal of Medical Entomology 42, 548-553.

Edillo, F.E., Tripét, F., Touré, Y.T., Lanzaro G. C., Dolo, G. \& Taylor, C.E. (2006) Water quality and immatures of the $\mathrm{M}$ and $\mathrm{S}$ forms of Anopheles gambiae s.s. and An. arabiensis in a Malian village. Malaria Journal 5:35. 
Edillo, F.E., Touré', Y.T., Lanzaro, G.C., Dolo, G. \& Taylor, E.T. (2002) Spatial distribution of Anopheles gambiae and Anopheles arabiensis (Diptera: Culicidae) in Bahaman village, Mali. Journal of Medical Entomology 39, 70-77.

Fanello, C., Santolamazza, F. \& della Torre, A. (2002) Simultaneous identification of species and molecular forms of Anopheles gambiae complex by PCR-RFLP. Medical and Veterinary Entomology 16, 461-464.

Finney, J.D. (1971) Probit analysis (3 ${ }^{\text {rd }}$. Edition). Cambridge University Press. Cambridge

Gillies, M.T. \& de Meillon, B. (1968) The Anophelinae of Africa South of Sahara (Ethiopian Zoographical Region). Publication of the South African Institute for Medical Research No. 54.

Gillies, M.T \& Coetzee, M. (1987) A Supplement to the Anophelinae of Africa, South of the Sahara. Publication of the South African Institute for Medical Research No. 55.

Gimnig, J.E., Ombok, M., Otieno, S., Kaufman, M.G., Vulule, J.M. \& Walker, E.D. (2002) Density-dependent development of Anopheles gambiae (Diptera: Culicidae) larvae in artificial habitats. Journal of Medical Entomology 39, 162-172.

Gimnig, J.E., Ombok, M., Kamau, L. \& Hawley, W.A. (2001) Characteristics of larval Anophelinae (Diptera: Culicidae) habitats in Western Kenya. Journal of Medical Entomology 38, 282-288.

Kahindi, S.C. (2005). Resistance mechanisms and susceptibility to organophosphates, carbamates and pyrethroids in Anopheles gambiae s.l. Giles (Diptera: Culicidae) in Hohoe district, Ghana. M.Phil Entomology Thesis. University of Ghana, Legon.

Klinkenberg, E., McCall, P.J., Hastings, I.M., Wilson, M.D., Amerasinghe, F.P. \& Donnelly, M.J. (2005) Malaria and Irrigated Crops, Accra, Ghana. Emerging Infectious Diseases 11: 8.

Lanzaro, G.C., Toure, T.Y., Carnahans, J., Zheng, L., Dolo, G., Traore, S.F., Petrarca, V., Vernick, K.D. \& Taylor, C.E. (1998) Complexities in the genetic structure of Anopheles gambiae populations in West Africa as revealed by microsatellite DNA analysis. Proceedings of the National Academy of Science 95, 14260-14265.

Martinez-Torres, D., Chandre, F., Williamson, M.S., Darriet, F., Berge, J.B., Devonshire, A.L., Guillet, P., Pasteur, N. \& Pauron, D. (1998) Molecular characterization of pyrethroid knockdown resistance $(\mathrm{kdr})$ in the major malaria vector Anopheles gambiae s.s. Insect Molecular Biology 7, 179-184.

Merritt, R.W., Dadd, R.H., Walker, E.D. (1992) Feeding behaviour, natural food and nutritional relationships of larval mosquitoes. Annual Review of Entomology 37, 349-376.

Midega, J.T. (2001) Cytological and molecular characterization of populations of the Anopheles gambiae Giles complex in costal savannah zone of Ghana. M. Phil. Thesis, University of Ghana, Legon.

Mukhtar, M., Herrel, N., Amerasinghe, F.P., Ensink, J., van der Hoek W. \& Konradsen, F. (2003) Role of wastewater irrigation in mosquito breeding in south Punjab, Pakistan. Southeast Asian Journal of Tropical Medicine and Public Health 34, 72-80.

Mwangangi, J.M., Mbogo, C.M., Muturi, E.J., Nzovu, J.G., Kabiru, E.W., Githure, J.I., Novak, R.J. \& Beier, J.C. (2007) Influence of biological and physicochemical characteristics of larval habitats on the body size of Anopheles gambiae mosquitoes (Diptera: Culicidae) along the Kenyan coast. Journal of Vector Borne Diseases 44, 122-127. 
Oo, T.T., Storch, V. \& Becker, N. (2002) Studies on the bionomics of Anopheles dirus (Culicidae: Diptera) in Mudon, Mon State, Myanmar. Journal of Vector Ecology 27, 44-54.

Otieno, J.O. (2004) Efficacy of deltamethrin-treated recycled net/curtain materials against different populations of Anopheles gambiae sensu lato Giles (Diptera: Culicidae in Southern Ghana. MPhil. thesis. University of Ghana, Legon.

Pfaehler, O., Oulo, D.O., Gouagna, L.C., Githure, J. \& Guerin, P.M. (2006) Influence of soil quality in the larval habitat on development of Anopheles gambiae Giles. Journal of Vector Ecology 31, 400-405.

Ramachandra Rao, T. (1984) The Anophelines of India revised edition. ICMR, New Delhi, India.

Reisen, W.K., Siddiqui, T.F., Aslamkhan, M. \& Malik, G.M. (1981) Larval inter-specific associations and physico-chemical relationships of the ground water breeding mosquitoes of Lahore. Pakistan Journal of Scientific Research 3, 1-23.

Rejmánková, E., Higashi, R., Grieco, J., Achee, N. \& Roberts, D. (2005) Volatile substances from larval habitats mediate species-specific oviposition in Anopheles mosquitoes. Journal of Medical Entomology 42, 95-103.

Robert, V., Awono-Ambene, H.P. \& Thioulouse, J. (1998) Ecology of larval mosquitoes, with special reference to Anopheles arabiensis (Diptera: Culicidae) in market-garden wells in urban Dakar, Senegal. Journal of Medical Entomology 35, 948-955.

Sattler, M.A., Mtasiwa, D., Kiama, M., Premji, Z., Tanner, M., Killeen, G.F. \& Lengeler,C. (2005) Habitat characterization and spatial distribution of Anopheles sp mosquito larvae in Dar es Salaam (Tanzania) during an extended dry period. Malaria Journal 4: 4.

Scott, J.A., Brogdon, W.G. \& Collins, F.H. (1993) Identification of single specimens of the Anopheles gambiae complex by the PCR. American Journal of Tropical Medicine and Hygiene $49,520-529$.

Sibomana, I. (2002). Investigation into the ecological determinants of distribution of Anopheles gambiae s.s. (Diptera: Culicidae) larval populations in urban Accra, Ghana. MPhil. Entomology Thesis. University of Ghana, Legon.

Strode, C., Steen, K., Ortelli, F. \& Ranson, H. (2006) Differential expression of the detoxification genes in the different life stages of the malaria vector Anopheles gambiae. Insect Molecular Biology 15, 523-530.

Taylor, C.E., Toure', Y.T. \& Carnahan, J. (2001) Gene flow among population of the malaria vector Anopheles gambiae, in Mali, West Africa. Genetics 157, 743-750.

Touré, Y.T., Petrarca, V., Traore, S.F., Coulibaly, A. \& Maiga, H.M. (1994) Ecological genetic studies in the chromosomal form of Mopti of Anopheles gambiae s.s. in Mali, West Africa. Genetica 94, 213-223.

Toure, Y.T., Petrarca, V., Traore, S.F., Coulibary, A., Maiga. H.M., Sankare, O., Sow, M., Di deco, M.A. \& Coluzzi, M. (1998). The distribution and inversion polymorphism of chromosomally recognized taxa of An. gambiae complex in Mali, West Africa. Parasitologia 40, 477-511.

Tripét, F., Toure', Y. T., Taylor, C.E., Norris, D.E., Dolo, G. \& Lanzaro, G. (2001) DNA analysis of transferred sperm reveals significant levels of gene flow between molecular forms of Anopheles gambiae. Molecular Ecology 10, 1725-1732.

Vulule, J.M., Beach, R.F., Atieli, F.K., Roberts. J.M., Mount, D.L. \& Mwangi, R.W. (1994) Reduced susceptibility of Anopheles gambiae to permethrin associated with the use of 
permethrin-impregnated bednets and curtains in Kenya. Medical and Veterinary Entomology 8, 71-75.

Wang, S.J., Lengeler, C., Smith, T.A., Vounatsou, P., Cisse, G., Diallo, D.A., Akogbeto, M., Mtasiwa, D., Teklehaimanot, A. \& Tanner, M. (2005) Rapid Urban Malaria Appraisal (RUMA) in sub Saharan Africa. Malara Journal 4:40.

Weill, W., Chandre, F., Brengues, C., Manguin, S., Akogbeto, M., Pasteur, N., Guillet, P. \& Raymond, M. (2000) The $k d r$ mutation occurs in the Mopti form of Anopheles gambiae s.s. through introgression. Insect Molecular Biology 9, 451

WHO (1975). Manual on Practical Entomology in Malaria. Part II. Methods and Techniques. WHO, Geneva, Switzerland

WHO (1998).Tests Procedures for Insecticide Resistance Monitoring in Malaria Vectors, Bio-Efficacy and Persistence of Insecticides on Treated Surfaces. Report of the WHO Informal Consultation. WHO, Geneva, Switzerland.

WHO (2000) World Health Organization Expert Committee Report on Malaria. 20 $0^{\text {th }}$ Report. Geneva, Switzerland.

Wondji, C., Simard, F. \& Fontenille, D. (2002) Evidence for genetic differentiation between the molecular forms $\mathrm{M}$ and $\mathrm{S}$ within the Forest chromosomal form of Anopheles gambiae in an area of sympatry. Insect Molecular Biology 11, 11-19.

Yawson, A.E., McCall, P.J., Wilson, M.D. \& Donnelly, M.J. (2004) Species abundance and insecticide resistance of Anopheles gambiae in selected areas of Ghana and Burkina Faso. Medical and Veternary Entomology 18, 372-377.

Ye-Ebiyo, Y., Pollack, R. J., Kiszewski, A. E. \& Spielman, A. (2003). A component of maize pollen that stimulates larval mosquitoes (Diptera: Culicidae) to feed and increases toxicity of microbial larvicides. Journal of Medical Entomology 40, 860-864. 